\title{
Abundance and expression of denitrifying genes (narG, nirS, nor $B$, and nosZ) in sediments of wastewater stabilizing constructed wetlands
}

\author{
Kyongmi Chon ${ }^{1}$, Jaeweon $\mathrm{Cho}^{1,2^{+}}$ \\ ${ }^{1}$ School of Civil and Environmental Engineering, Yonsei University, Seoul 120-749, Korea \\ ${ }^{2}$ School of Urban and Environmental Engineering, UNIST, Ulsan 689-798, Korea
}

\begin{abstract}
As expected, the expression of denitrifying genes in a Typha wetland (relatively stagnant compared to other ponds), showing higher nitrogen removal efficiency in summer, was affected by temperature. The abundance and gene transcripts of nitrate reductase (narG), nitrite reductase (nirS), nitric oxide reductase (norB), and nitrous oxide reductase (nosZ) genes in seasonal sediment samples taken from the Acorus and Typha ponds of free surface flow constructed wetlands were investigated using quantitative polymerase chain reaction (Q-PCR) and quantitative reverse transcription PCR (Q-RT-PCR). Denitrifying gene copy numbers $\left(10^{5}-10^{8}\right.$ genes $\mathrm{g}^{-1}$ sediment) were found to be higher than transcript numbers$\left(10^{3}-10^{7}\right.$ transcripts $\mathrm{g}^{-1}$ sediment) of the Acorus and Typha ponds, in both seasons. Transcript numbers of the four functional genes were significantly higher for Typha sediments, in the warm than in the cold season, potentially indicating greater bacterial activity, during the relatively warm season than the cold season. In contrast, copy numbers and expression of denitrifying genes of Acorus did not provide a strong correlation between the different seasons.
\end{abstract}

Keywords: Constructed wetland, Denitrifying genes, quantitative polymerase chain reaction (Q-PCR), quantitative reverse transcription polymerase chain reaction (Q-RT-PCR), Sediments

\section{Introduction}

Constructed wetlands have been used to remove nitrate from wastewater effluents after conventional treatment processes [1-3]. Denitrification is considered as a major nitrogen removing mechanism, which transforms $\mathrm{NO}_{3}{ }^{-}$and $\mathrm{NO}_{2}{ }^{-}$to the gases $\mathrm{NO}, \mathrm{N}_{2} \mathrm{O}$ and $\mathrm{N}_{2}$ in various constructed wetlands and is a critical process of the nitrogen cycle [4]. Denitrification is carried out by heterotrophic bacteria under anoxic or anaerobic conditions [5]. Denitrifying bacteria use nitrate as an electron acceptor, which is reduced to nitrogen gas. The reduction of $\mathrm{NO}_{3}{ }^{-}$to gaseous forms of nitrogen is catalyzed by several reductases [6].

Functional genes that encode key enzymes, such as nitrate, nitrite, nitric oxide, and nitrous oxide reductase in the denitrification pathway, have been exploited as molecular markers for qualitative and quantitative studies of denitrifiers in the environment. The reduction of soluble nitrate to nitrite is catalyzed by either a membrane-bound (nar) or a periplasmic nitrate red- cutase (nap), which is encoded by the narG or the napA gene, respectively [7]. The reduction of soluble nitrite to nitric oxide gas is catalyzed by either a cyto-chrome $c d_{1}$ nitrite reductase (encoded by nirS) or a copper nitrite reductase (encoded by nirK) [8-10]. The reduction of $\mathrm{NO}$ to $\mathrm{N}_{2} \mathrm{O}$ is catalyzed by two nitric oxide reductases, $c N O R$ (cytochrome c electron donor) and qNOR (quinol electron donor) [11]. cNor is the most commonly observed indenitrifiers. qNor has also been found in some denitrifiers but also in non-denitrifying microorganisms with a detoxification function against nitric oxide [12, 13]. The last step of the denitrification pathway, the reduction of nitrous oxide to dinitrogen, is catalyzed by nitrous oxide reductase (encoded by the nos $Z$ ) which exists in the periplasm [14-16].

Quantitative polymerase chain reaction (Q-PCR) is now widely used in microbial ecology since it is a highly reproducible, sensitive, and robust method to determine functional gene abundances under varying environmental or experimental conditions [17]. Q-PCR has been applied to quantify the copy numbers of denitrifying functional genes in various environmental samples [18-22].
This is an Open Access article distributed under the terms of the Creative Commons Attribution Non-Commercial License (http://creativecommons. org/ licenses/by-nc/3.0/) which permits unrestricted non-commercial use, distribution, and reproduction in any medium, provided the original work is properly cited.
Received October 11, 2014 Accepted January 14, 2015

$\uparrow$ Corresponding author

Email: jaeweoncho@unist.ac.kr

Tel: +82-52-217-2823 Fax: +82-52-217-2819

Copyright (c) 2015 Korean Society of Environmental Engineers 
Combining Q-PCR with an initial reverse transcription (RT) reaction facilitates the quantification of gene transcript numbers in environmental systems, enabling quantitative estimates of the metabolic activity of functional genes in the environment. The application of quantitative reverse transcription PCR (Q-RT-PCR) to environmental samples has been limited to the quantification of functional gene transcripts from aqueous system, individual species and soils [23-25]. This technique has been applied to quantify the denitrification gene transcripts in estuarine sediments [26], to evaluate the denitrifying gene expression in Thiobacillus denitrificans under denitrifying conditions [27] and to evaluate the effect of complex carbon sources on the denitrifier mRNA levels in agricultural soils [28]. However, there have been relatively few studies on the abundance and gene expression of denitrifying bacteria using Q-PCR and Q-RT-PCR methods in constructed wetlands. Therefore, little is known about the role of denitrifying bacteria with regard to nitrogen control in constructed wetlands.

The objectives of this study were to quantify the abundance and transcripts of key denitrifying functional genes (narG, nirS, norB, and nosZ), with respect to controls of nitrate, in constructed wetland, using SYBR green based both Q-PCR and Q-RT-PCR. To our knowledge, this is the first report on the expression of denitrifying functional genes in response to nitrogen removal and seasonal changes in wastewater stabilizing constructed wetlands.

\section{Materials and Methods}

\subsection{Site Description and Sampling}

All sediment samples were collected in triplicate from the Damyang surface-flow constructed wetlands $\left(35^{\circ} 18^{\prime} \mathrm{N}, 126^{\circ} 58^{\prime} \mathrm{E}\right)$ on September 3rd $\left(25^{\circ} \mathrm{C}\right)$ and November 17 th $\left(10^{\circ} \mathrm{C}\right), 2009$. The wetlands consist of two different ponds, with Acorus and Typha plants dominating one pond each. The Acorus pond was further upstream than the Typha pond, each of which acts as tertiary treatment systems between the wastewater effluent and the downstream wetlands system. The water characteristics for each pond have been previously described by Chon et al. [29]. Removal efficiency of total nitrogen (TN) was higher in September than in November, in the Typha pond, indicating that the denitrification rate was affected by temperature. The flow rate and hydraulic retention time (HRT) of the whole wetland system was designed to be approximately $1,800 \mathrm{~m}^{3} /$ day and $6 \mathrm{hr}$, respectively. The whole wetland dimensions were: $120 \mathrm{~m} \times 30 \mathrm{~m} \times 0.13 \mathrm{~m}$ (length $\times$ width $\times$ depth) [22]. The soil layers in the Acorus wetland consist of a porous media, which provide habitats for microorganisms. In contrast, the Typha wetland soil has been classified as a loamy sand. Sediment samples were transported to the laboratory in an ice box, and were then homogenized and divided into aliquots and frozen at $-80^{\circ} \mathrm{C}$ until further molecular analysis.

\subsection{DNA Extraction}

Soil DNA was extracted in triplicate using the PowerSoil DNA isolation Kit (PowerSoil; Mobio laboratories Inc., CA, USA), according to the manufacturer's instructions. The concentration of DNA was also determined at $260 \mathrm{~nm}$ using a Nano-drop spectrophotometer. DNA extracts were stored at $-20^{\circ} \mathrm{C}$ until further analysis.

\subsection{Total RNA Extraction and cDNA Synthesis}

Total RNA was extracted from 1.5 g sediment samples using the RNA PowerSoilTM total RNA isolation Kit (PowerSoil; Mobio laboratories Inc., CA, USA), according to the manufacturer's instructions. Extraction of RNA was confirmed by gel electrophoresis. Aliquots of total RNA sample was digested with DNase I (Takara, Japan) according to the provided instructions. After incubation for 30 min at $37^{\circ} \mathrm{C}$, phenol/chloroform extraction was performed to inactivate DNase I. Purified precipitated RNA samples were resuspended in Diethyl Pyrocarbonate (DEPC) treated water. Genomic DNA was confirmed to be removed completely by gel electrophoresis. Extracts were stored at $-80^{\circ} \mathrm{C}$ prior to use. RNA purity was assessed by the A260/A280 ratio, with range of 1.9-2.1.

\subsection{Primers Design}

Table 1 lists the details of primers used for the amplification of denitrifying functional genes (narG, nirS, norB, and nosZ). All the designed primers were synthesized by Xenotech (Daejeon, Korea).

\subsection{PCR Conditions}

PCR amplification of denitrifying functional genes from soil samples was performed to prepare Q-PCR standards and to confirm the specificity of amplicons. PCR amplification of narG, nirS, norB and nos $Z$ genes was performed at a total volume of $20 \mu \mathrm{L}$ in a mastercycler (Eppendorf Mastercycler personnel, Germany). The PCR mixture consisted of PCR premix (AccuPower PCR PreMixkit; Bioneer, Korea), $1 \mu \mathrm{L}$ of $10 \mathrm{pmol}$ of each primer, and $30 \mathrm{ng}$ of

Table 1. Primer Sets Used for Q-PCR

\begin{tabular}{|c|c|c|c|}
\hline Functional gene & Primer & Primer sequence $\left(5^{\prime}-3^{\prime}\right)$ & Reference \\
\hline \multirow[t]{2}{*}{ narG } & narG1960m2f & TAY GTS GGG CAG GAR AAA CTG & \multirow[t]{2}{*}{ [30] } \\
\hline & narG2050m2r & CGT AGA AGA AGC TGG TGC TGT & \\
\hline \multirow{2}{*}{$\operatorname{nirS}$} & niS2F & TAC CAC CCS GAR CCG C GC GT & \multirow{2}{*}[8]{} \\
\hline & nirS3R & GCC GCC GTC RTG VAG GAA & \\
\hline \multirow[t]{2}{*}{ norB } & cnorB2F & GAC AAG NNN TAC TGG TGG T & \multirow{2}{*}{ [11] } \\
\hline & cnorB6R & GAA NCC CCA NAC NCC NGC & \\
\hline \multirow[t]{2}{*}{ nosZ } & nosZF & AGA ACG ACC AGC TGA TCG ACA & \multirow[t]{2}{*}[22]{} \\
\hline & nosZR & TCC ATG GTG ACG CCG TGG TTG & \\
\hline
\end{tabular}

Q-PCR: quantitative polymerase chain reaction. 
template DNA.

The thermal cycling conditions for nar $G$ amplification were $10 \mathrm{~min}$ at $95^{\circ} \mathrm{C}, 6$ cycles of $95^{\circ} \mathrm{C}$ for $30 \mathrm{sec}, 63^{\circ} \mathrm{C}$ for $30 \mathrm{sec}$ with a touchdown of $-1^{\circ} \mathrm{C}$ by cycle, and $72^{\circ} \mathrm{C}$ for $30 \mathrm{sec}, 35$ cycles with annealing at $58^{\circ} \mathrm{C}$. The conditions for nirS included $95^{\circ} \mathrm{C}$ for $10 \mathrm{~min}, 35 \mathrm{cycles}$ at $95^{\circ} \mathrm{C}$ for $30 \mathrm{sec}, 61^{\circ} \mathrm{C}$ for $30 \mathrm{sec}$, and $72^{\circ} \mathrm{C}$ for $30 \mathrm{sec}$; followed by a final extension step at $72^{\circ} \mathrm{C}$ for $10 \mathrm{~min}$. The norB PCR amplification conditions included $95^{\circ} \mathrm{C}$ for $10 \mathrm{~min}, 10$ cycles at $95^{\circ} \mathrm{C}$ for $30 \mathrm{sec}, 30 \mathrm{sec}$ of primer annealing with a touch down from 61 to $55^{\circ} \mathrm{C}$, and $72^{\circ} \mathrm{C}$ for 30 sec, 30 cycles with annealing at $55^{\circ} \mathrm{C}$. PCR amplification of nos $Z$ included $10 \mathrm{~min}$ at $95^{\circ} \mathrm{C}, 35$ cycles of $95^{\circ} \mathrm{C}$ for $30 \mathrm{sec}, 60^{\circ} \mathrm{C}$ for $30 \mathrm{sec}$, and $72^{\circ} \mathrm{C}$ for $30 \mathrm{sec}$; followed by a final extension step at $72^{\circ} \mathrm{C}$ for $5 \mathrm{~min}$. All the PCR products were analyzed on $1.5 \%(\mathrm{w} / \mathrm{v})$ ethidium bromide-stained agarose gels to ensure the correct size fragment was amplified.

\subsection{Q-PCR and Q-RT-PCR Standard Curves}

The PCR amplicons were purified using the AccuPrep PCR purification kit (k-3034; Bioneer, Korea). The purified PCR products were ligated into the $\mathrm{yT} \& \mathrm{~A}$ cloning vector (RBC, Twain) using the protocol provided in the yT\&A Cloning kit and transformed into HIT-DH5 $\alpha$ (RH617; RBC, Twain) cells. Transformants were selected on Luria-Bertani agar plates containing ampicillin (70 $\mu \mathrm{g} / \mathrm{mL}), 20 \mu \mathrm{L}$ of 5-bromo-4-chloro-3-indolyl- $\Omega$-D-galactoside (X-gal) $(40 \mathrm{mg} / \mathrm{mL})$, and $8 \mu \mathrm{L}$ of isopropyl-beta-D-thiogalactopyranoside (IPTG) (40 $\mathrm{mg} / \mathrm{mL}$ ). A single white colony containing the recombinant plasmids was inoculated into $200 \mu \mathrm{L}$ Luria-Bertani (LB) broth containing ampicilin $(70 \mu \mathrm{g} / \mathrm{mL})$, and incubated at $37^{\circ} \mathrm{C}$ for $4-5$ hours. The plasmid DNA was prepared by the Gene All quick plasmid kit (GeneAll Biotechnology, Korea) according to the manufacturer's protocol. The plasmid concentrations were measured by a Nano-drop Spectrophotometer using the absorbance at $260 \mathrm{~nm}$. Plasmids containing the fragments were linearized using the XbaI (Takara, Japan) restriction enzyme. The presence of the appropriate insert in the recombinant plasmids was verified by PCR amplification using the corresponding primers. Serially diluted linearized plasmid with $10^{3}$ to $10^{8}$ gene copies $\mu \mathrm{L}^{-1}$ was used as standards. Standard curves for the narG, nirS, norB, and nos $Z$ assays were generated by plotting the threshold cycle $(\mathrm{Ct})$ values against $\log 10$ of the gene copy numbers. The amplification efficiency (E) was calculated from the slope of the standard curve through the following formula: $\mathrm{E}=\left(10^{-1 / \mathrm{slope}}\right)-1$.

Q-RT-PCR standards were produced by in vitro transcription of the target functional genes. The target gene amplicon was ligated into the yT\&A cloning vector (RBC, Twain) and transformed into HIT-DH5 $\alpha$ (RH617, RBC) cells. Transformants were selected on $\mathrm{LB}$ agar plates containing $70 \mu \mathrm{g} / \mathrm{mL}$ ampicillin, $20 \mu \mathrm{L}$ of $40 \mathrm{mg} / \mathrm{mL}$ $\mathrm{X}$-gal, and $8 \mu \mathrm{L}$ of $40 \mathrm{mg} / \mathrm{mL}$ IPTG. A single white colony containing the recombinant plasmids was inoculated into $200 \mu \mathrm{L} \mathrm{LB}$ broth with $70 \mu \mathrm{g} / \mathrm{mL}$ ampicilin, and incubated at $37^{\circ} \mathrm{C}$ for $4-5$ hours. The plasmid DNA was then extracted and purified using the Gene All quick plasmid kit (GeneAll Biotechnology, Korea). The plasmid concentrations were assessed by measuring absorbance at 260 nm using a Nano-drop Spectrophotometer. The presence of the appropriate insert in the recombinant plasmids was verified by
PCR with the insert reverse primer and the vector primer M13F. The amplicons were purified using the AccuPrep PCR purification kit (k-3034; Bioneer, Korea) and used for by in vitro transcription using the MEGAshortscriptTM kit (Ambion). The in vitro transcription reaction $(20 \mu \mathrm{L})$ contained template DNA, $75 \mathrm{mM}$ of each ribonucleotide, $10 \times$ reaction buffer and $1 \times$ T7 enzyme mix. The reaction was incubated at $37^{\circ} \mathrm{C}$ for $4 \mathrm{hr}$. The DNA template was removed from the reaction by treatment with $1 \mu \mathrm{L}$ of TURBO DNase (Ambion) at $37^{\circ} \mathrm{C}$ for $5 \mathrm{~min}$. The reaction was terminated by adding $115 \mu \mathrm{L}$ nuclease-free water and $15 \mu \mathrm{L}$ 3M sodium acetate. Phenol:chloroform extraction followed by alcohol precipitation were performed to remove all enzymes and most of the free nucleotides from the reactions. RNA concentration was measured using a Nano-drop Spectrophotometer at $230 \mathrm{~nm}$. The transcripts were loaded and analyzed in 1\% agarose gel after heating with Gel loading Buffer (Ambion) for $3 \mathrm{~min}$ at $95^{\circ} \mathrm{C}$. All RNA samples were stored in aliquots at $-80^{\circ} \mathrm{C}$ until use. Each RNA was individually reverse transcribed, and the cDNA from RT reaction was used to create a serial dilution, which was subsequently used as template for the standard curve.

\subsection{Calculation of Copy Numbers}

The copy number for Q-PCR standards were calculated by assuming a molecular mass of $660 \mathrm{Da}$ for double-stranded DNA and $330 \mathrm{Da}$ for single-stranded RNA. The calculation was done with the following equations: Copy number $=$ concentration of standard $(\mathrm{g} / \mu \mathrm{L}) \times$ Avogadro constant $\left(6.02 \times 10^{23}\right.$ copies/mole $) / \mathrm{MW}$ $(\mathrm{g} / \mathrm{mol})$

\subsection{Q-PCR and Q-RT-PCR Analysis}

The Q-PCR assay was performed on the Rotor-Gene 6000 (Corbett research, NSW, Australia). Q-PCR assays were performed within a single plate to generate both a DNA standard curve, a cDNA standard curve, and to quantify the numbers of denitrifying functional genes (narG, nirs, norB, and nosZ) from the environmental DNA and cDNA templates. Each assay was conducted in a 72-well rotor with each standard, no template controls (NTC), and three replicate DNA and cDNA samples. Both triplicate DNA and cDNA samples were amplified in triplicate within individual Q-PCR assays. Amplification reactions were performed in a volume of $20 \mu \mathrm{L}$ and the reaction mixture contained $10 \mu \mathrm{L} 2 \times$ SensiMixPlus (Quantace, Norwood, MA), $0.25 \mu \mathrm{M}$ of each primer, $1 \mu \mathrm{L}$ of template $\mathrm{DNA} / \mathrm{cDNA}$, and RNase-free water.

The thermal cycling steps of the Q-PCR for narG amplification were $10 \mathrm{~min}$ at $95^{\circ} \mathrm{C}, 6$ cycles of $95^{\circ} \mathrm{C}$ for $10 \mathrm{sec}, 63^{\circ} \mathrm{C}$ for 15 sec with a touchdown of $-1^{\circ} \mathrm{C}$ by cycle, and $72^{\circ} \mathrm{C}$ for $20 \mathrm{sec}$, and $81^{\circ} \mathrm{C}$ for $15 \mathrm{sec}$ (acquisition data step); 35 cycles with annealing at $58^{\circ} \mathrm{C}$. The nirS PCR amplification conditions included $95^{\circ} \mathrm{C}$ for $10 \mathrm{~min}, 35$ cycles at $95^{\circ} \mathrm{C}$ for $10 \mathrm{sec}, 61^{\circ} \mathrm{C}$ for $15 \mathrm{sec}$, and $72^{\circ} \mathrm{C}$ for 20 sec. The PCR conditions for norB amplication were $10 \mathrm{~min}$ at $95^{\circ} \mathrm{C}, 10$ cycles of $10 \mathrm{sec}$ at $95^{\circ} \mathrm{C}, 15 \mathrm{sec}$ of primer annealing with a touch down from 57 to $53^{\circ} \mathrm{C}$, primer extension of $30 \mathrm{sec}$ at $72^{\circ} \mathrm{C}$, and an additional 40 cycles with a constant annealing temperature of $53^{\circ} \mathrm{C}$. PCR amplification of nos $Z$ included $10 \mathrm{~min}$ at $95^{\circ} \mathrm{C}, 40$ cycles of $95^{\circ} \mathrm{C}$ for $10 \mathrm{sec}, 60^{\circ} \mathrm{C}$ for $15 \mathrm{sec}$, and $72^{\circ} \mathrm{C}$ for 30 sec. The specificity of each PCR assay was confirmed 
using both melting curve analysis and agarose gel electrophoresis. Two independent Q-PCR assays were performed on each of the three replicate soil DNAs. Unknown DNA/cDNA samples were quantified against standard curves using RotorGene 6000 series softwear v. 1.7 (Corbett research, NSW, Australia). The coefficient of determination (r2), the slope, and the y-intercept value for each standard curve were determined. In addition, the amplification efficiency (E) was estimated using the slope of the standard curve through the following formula: $E=\left(10^{-1 / \text { slope }}\right)-1$. In order to test for an inhibitory effect of soil DNA on PCR amplification, Q-PCR was conducted by spiking soil DNA with control plasmid DNA. In addition, serial dilutions of soil DNA were quantified and compared.

Two-step Q-RT-PCR was carried out. RT reaction was performed by using PrimeScript ${ }^{\mathrm{TM}}$ RT reagent Kit (Takara, Japan), according to the manufacturer's instructions. The initial $10 \mu \mathrm{L}$ volume RT reaction was performed as follows: $1 \mu \mathrm{L}$ of RNA standard or 1 $\mu \mathrm{L}$ of environmental RNA, 25 pmol of oligo dT primer, 50 pmol of Random 6 mers, $0.5 \mu \mathrm{L}$ of PrimeScript TM RT Enzyme Mix, and $2 \mu \mathrm{L}$ of PrimeScript TM Buffer was made up to a final volume of $10 \mu \mathrm{L}$ with $\mathrm{RNase}$ Free $\mathrm{dH}_{2} \mathrm{O}$. The reaction was incubated at $37^{\circ} \mathrm{C}$ for $15 \mathrm{~min}$, followed by inactivation of the reaction at $85^{\circ} \mathrm{C}$ for 5 sec. $1 \mu \mathrm{L}$ of the first strand cDNA synthesized in this reaction was amplified by Q-PCR using the same reaction and cycling conditions as described above.

\subsection{Data Analysis}

Two independent Q-PCR assays were carried out on each of the three replicate soil DNA/RNA extracts. One way analysis of variance (ANOVA) was performed, using SPSS v. 15., for each wetland soil in order to observe differences in functional gene copy numbers and their transcripts between sites and sampling dates. Data were log or square root transformed to meet the ANOVA premises. Means were compared using the least significant difference (LSD) test at $p<0.05$.

\section{Results and Discussion}

\subsection{Production of Standard Curves for Q-PCR and Q-RT-PCR}

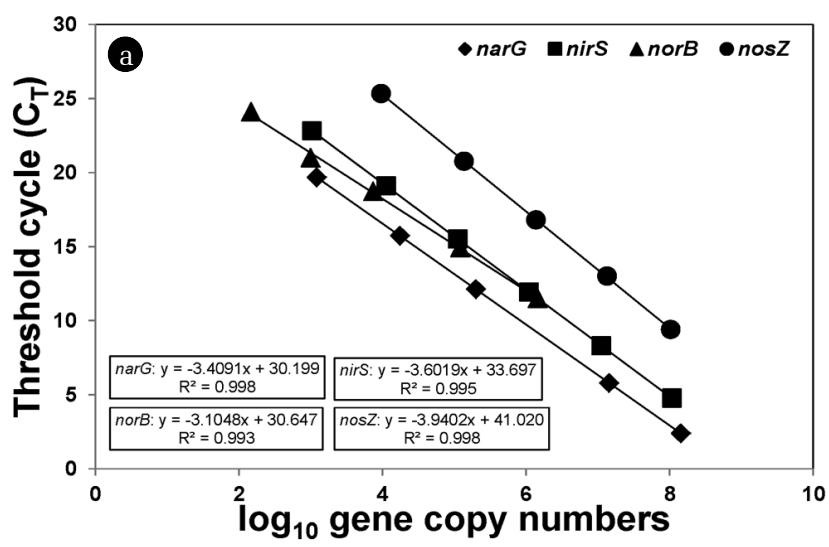

Standard curves for Q-PCR and Q-RT-PCR were generated by preparing 10-fold dilutions of four plasmids and four cDNA solutions containing narG, nirS, norB, and nosZ genes, respectively. All standard curves exhibited linearity between $10^{2}-10^{8}$ copies for Q-PCR and $10^{3}-10^{8}$ copies for Q-RT-PCR, and had high correlation coefficients of $\mathrm{r}^{2}>0.99$ for Q-PCR and Q-RT-PCR. The calculated Q-PCR and Q-RT-PCR efficiencies for narG, nirS, norB, and nosZ genes were 96\%, 95\%, 108\%, and 80\% (Fig. 1(a)) and 98\%, 100\%, $82 \%$, and $89 \%$, respectively (Fig. 1(b)).

\subsection{Q-PCR Quantification of Denitrifying Genes (narG, nirS, nor $B$, and nos $A$}

Q-PCR assays were used to investigate the abundance of narG, nirS, norB, and nosZ genes in the sediment samples taken from Acorus and Typha wetlands in September and November 2009, using the primer sets described in Table 1. The density of nirS, norB, and nosZ in Acorus and Typha sediments ranged between $10^{7}$ and $10^{8}$ copies $g^{-1}$ of sediment according to sampling date, whereas narG gene density was between $10^{5}$ and $10^{6}$ copies $^{-1}$ of sediment (Fig. 2).

The copy numbers of narG and nirS genes found in the Acorus system were higher than those found in the Typha wetland in both September and November $(p<0.05)$, while the gene copy numbers for norB and nosZ found at Typha system were higher than those found at Acorus in both September and November $(p<0.05)$. The higher abundance of narG and nirS gene copy numbers in Acorus is in good agreement with our previous study. We confirmed that the first $\left(\mathrm{NO}_{3}{ }^{-}\right.$to $\left.\mathrm{NO}\right)$ and second ( $\mathrm{NO}$ to $\mathrm{N}_{2}$ ) half denitrification procedures were dominant in the Acorus and Typha wetlands, respectively, during the summer season by using Q-PCR and acetylene-block techniques [31].

Gene copy numbers of nirS and norB were significantly higher in Typha sediments in September than in November, but there was no significant difference determined for narG and nos $Z$ gene copy numbers in Typha sediments between September and November. Gene copy numbers of narG were significantly higher in Acorus sediments in September than in November, but nos $Z$ gene copy numbers were significantly greater in Acorus sediments in

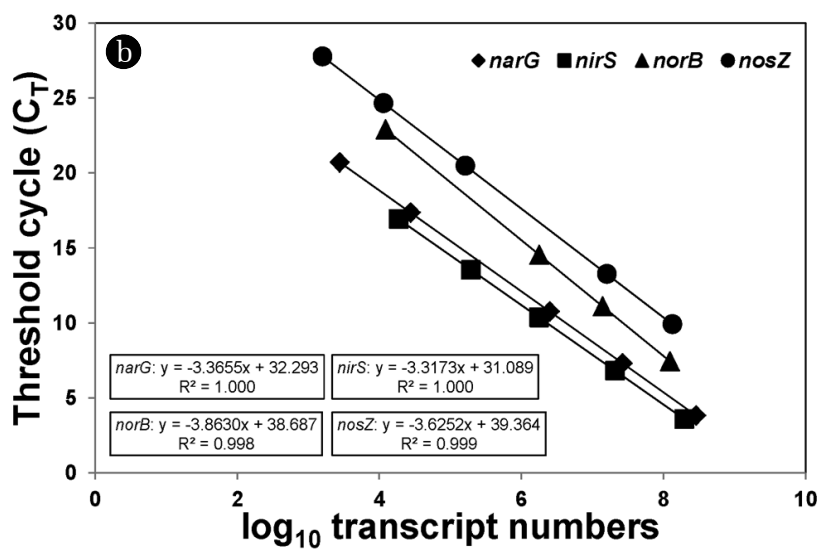

Fig. 1. Standard curves of narG, nirS, norB, and nosZ Q-PCR assays obtained by calculating (a) gene copy numbers versus threshold cycle, and (b) transcript numbers versus threshold cycle. 

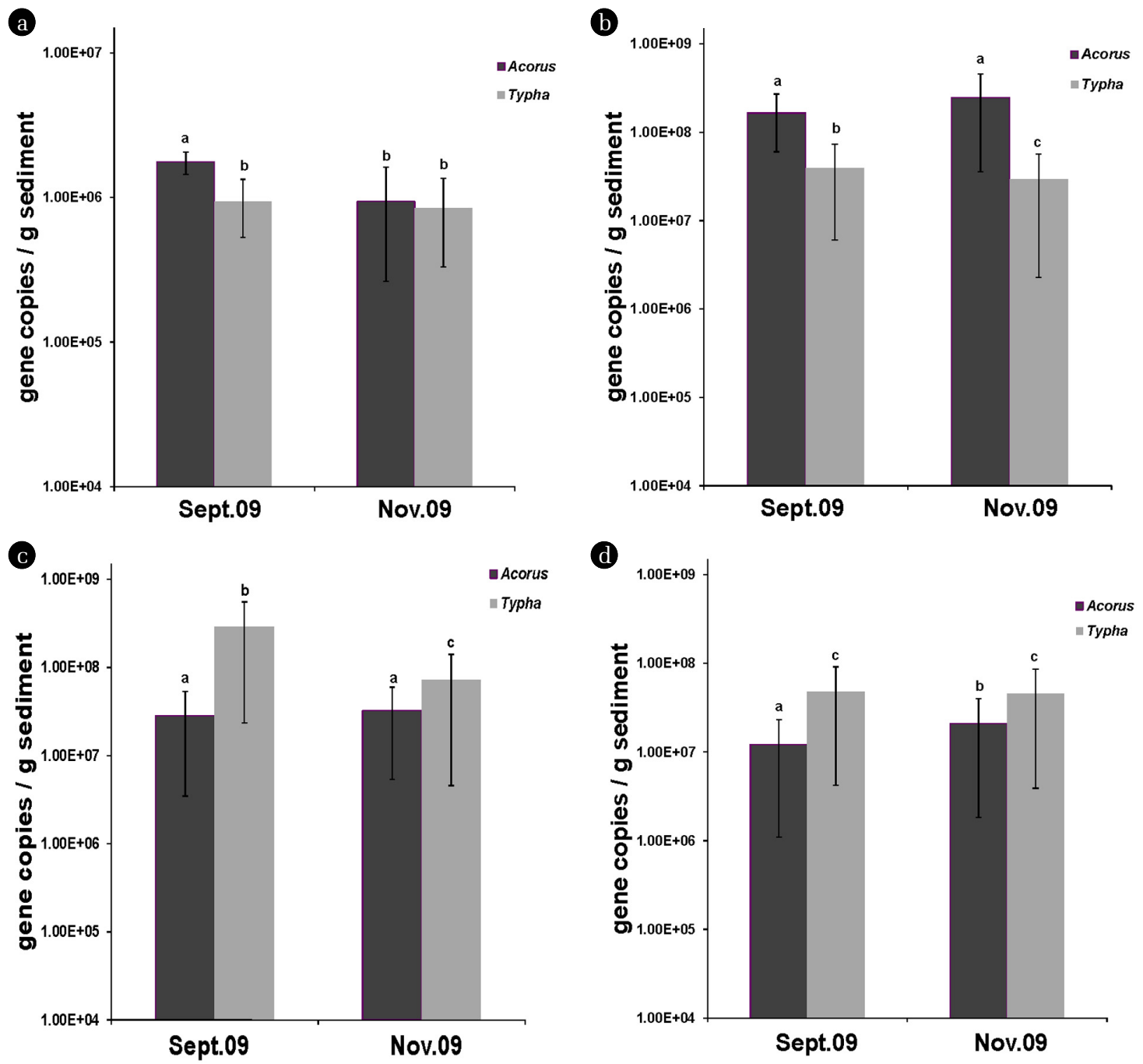

Fig. 2. Variation in gene abundance (copy number $\mathrm{g}^{-1}$ sediment) of narG (a), nirS (b), norB (c), nosZ (d) in Damyang constructed wetlands in September and November 2009. Error bars indicate standard errors of the two independent PCRs of the three replicate DNA extractions. Significantly different values $(p<0.05)$ between sites and sampling dates are marked by lowercase letters (a to c).

November than in September. There were no significant differences determined for nirS and norB gene copy numbers in Acorus sediments between September and November. The copy numbers of denitrifying genes of Acorus and Typha wetlands did not seem to strongly correlate with seasonal variation. This result is in agreement with our previous study, which showed little correlation of denitrifying genes (narG, nirS, and nosZ) with seasonal variation [22]. It should be noted that the density of functional genes in environmental samples may not be always linked to bacterial activity, contrary to our expectation.

\subsection{Q-RT-PCR Quantification of Denitrifying Genes Transcript Numbers (narG, nirS, norB, and nos )}

Q-RT-PCR assays were used to investigate variation in the levels of narG, nirS, norB, and nosZ gene expression using RNA extracted from Acorus and Typha sediments in September and November
2009. The gene transcripts of narG, and nosZ in Acorus and Typha sediments ranged between $10^{3}$ and $10^{8}$ trancripts $\mathrm{g}^{-1}$ of sediment according to sampling date, whereas nirS and norB gene transcripts ranged between $10^{5}$ and $10^{7}$ transcripts $\mathrm{g}^{-1}$ of sediment (Fig. 3).

Transcript numbers for narG, nirS, norB, and nosZ genes were significantly higher in Typha sediments in September than in November, indicating that denitrifying activities are higher during the warm season than during the cold season. It shows good agreement with our previous results representing higher nitrogen removal efficiency at the Typha pond of the same wetlands in summer. There was no significant difference observed for nirS and nos $Z$ transcript numbers in Acorus sediments between September and November. However, the narG transcript numbers were significantly greater in Acorus sediments in November than in September, and the norB transcript numbers were sig- 

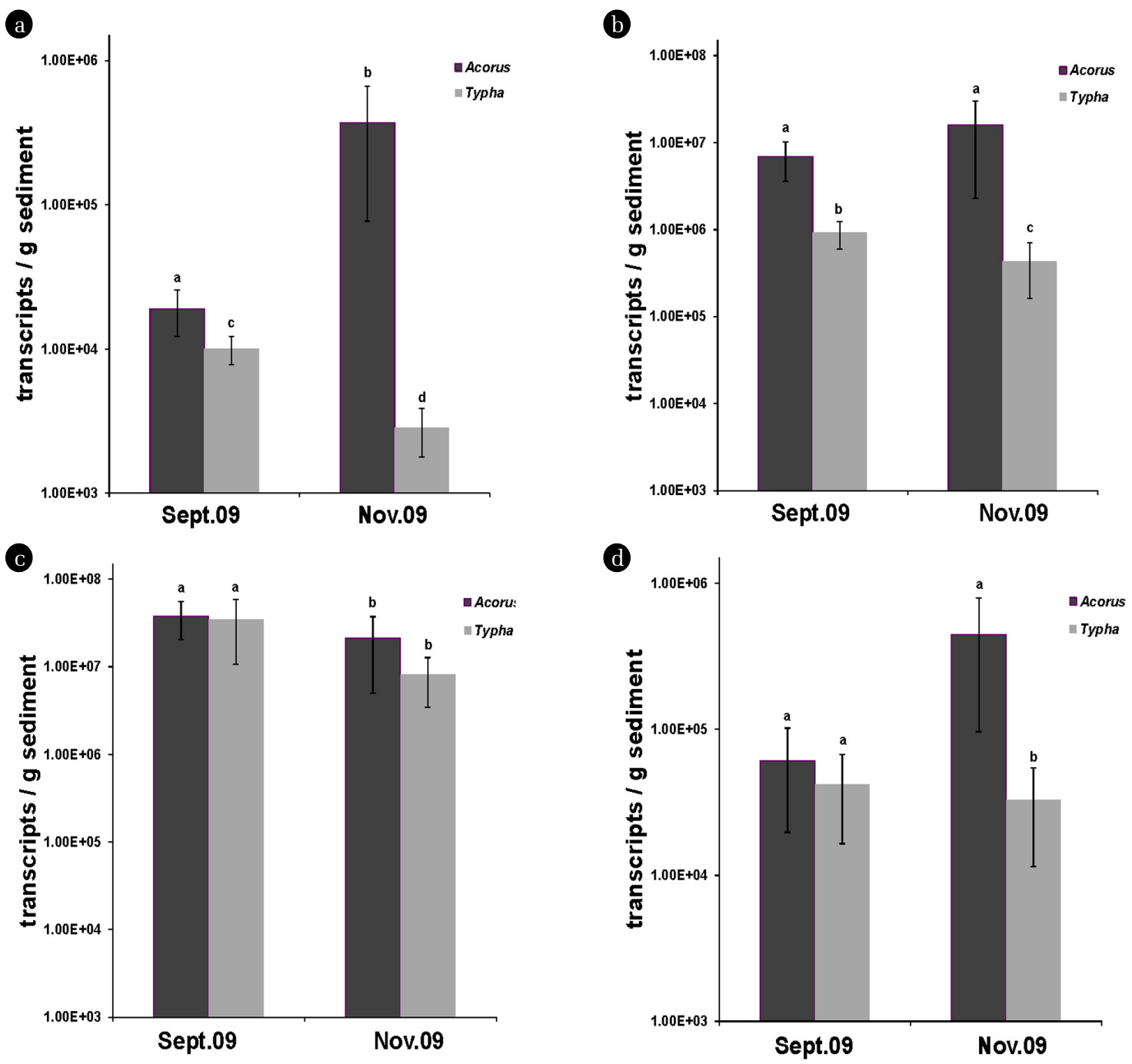

Fig. 3. Variation in gene transcripts numbers (transcripts $g^{-1}$ sediment) of narG (a), nirS (b), norB (c), nosZ (d) genes in Damyang constructed wetlands in September and November 2009. Error bars indicate standard errors of the two independent PCRs of the three replicate cDNAs. Significantly different values $(p<0.05)$ between sites and sampling dates are marked by lowercase letters (a to c).

nificantly higher in Acorus sediments in September than in November. The narG and nirS transcript numbers were significantly higher at Acorus than at Typha in both September and November. Gene copy numbers and transcript numbers of denitrifying functional genes in Acorus wetland were not correlated strongly with the seasonal differences. These results are in good agreement with the nitrate data shown in our previous study [29] indicating that there was no significant difference in nitrate removal efficiency in Acorus wetland between September and November.

\section{Conclusions}

SYBR based Q-PCR and Q-RT-PCR were developed and applied to quantify the abundance and expression of denitrifying genes
(narG, nirS, norB, and nosZ) in Acorus and Typha wetlands in summer and winter. Denitrifying gene copy numbers $\left(10^{5}-10^{8}\right.$ genes $\mathrm{g}^{-1}$ sediment) were higher than transcript numbers $\left(10^{3}-10^{7}\right.$ transcripts $\mathrm{g}^{-1}$ sediment) of the Acorus and Typha ponds in both seasons. Transcript numbers of the four key functional genes were significantly higher in the Typha pond in September than in November, potentially indicating greater bacterial activity during the warmer season than the colder one. It shows good agreement with our previous results representing higher nitrogen removal efficiency at the Typha pond of the same wetlands in summer. In contrast, the transcript numbers of denitrifying genes of Acorus did not seem to correlate strongly with seasonal differences. Integrated studies on the diversity and distribution of denitrifying functional genes can be further implemented to enhance our understanding of bacterial denitrification in constructed wetlands receiving wastewater effluent. 


\section{Acknowledgements}

This work was supported by the National Research Foundation of Korea (NRF) grant funded by the Korean government (MEST) (No. 2012047029) and ERC (No. 2011-0030842).

\section{References}

1. Kadlec RH. Nitrogen farming for pollution control. J. Environ. Sci. Health. 2005;40:1307-1330.

2. Park N, Kim JH, Cho J. Organic matter, anion, and metal wastewater treatment in Damyang surface flow constructed wetlands in Korea. Ecol. Eng. 2008;32:68-71.

3. Vymazal J. Removal of nutrients in various types of constructed wetlands. Sci. Total Environ. 2007;380:48-65.

4. Bachand PAM, Horne AJ. Denitrification in constructed free-water surface wetlands: II. Effects of vegetation and temperature. Ecol. Eng. 1999;14:17-32.

5. Lee CG, Fletcher TD, Sun G. Nitrogen removal in constructed wetland systems. Eng. Life Sci. 2009;9:11-22.

6. Philippot L, Hallin S, Schloter M. Ecology of denitrifying prokaryotes in agricultural soil. Adv. Agron. 2007;96:249-305.

7. Bru D, Sarr A, Philippot L. Relative abundances of proteobacterial membrane-bound and periplasmic nitrate reductases in selected environments. Appl. Environ. Microbiol. 2007;73:59715974.

8. Braker G, Fesefeldt A, Witzel KP. Development of PCR primer systems for amplification of nitrite reductase genes (nirK and nirS) to detect denitrifying bacteria in environmental samples. Appl. Environ. Microbiol. 1998;64:3769-3775.

9. Braker G, Zhou J, Wu L, Devol AH, Tiedje JM. Nitrite reductase genes (nirK and nirS) as functional markers to investigate diversity of denitrifying bacteria in Pacific Northwest marine sediment communities. Appl. Environ. Microbiol. 2000;66:20962104.

10. Henry S, Baudoin E, López-Gutiérreza JC, Martin-Laurent F, Brauman A, Philippot L. Quantification of denitrifying bacteria in soils by nirK gene targeted real-time PCR. J. Microbiol. Methods. 2004;59:327-335.

11. Braker G, Tiedje JM. Nitric oxide reductase (norB) genes from pure cultures and environmental samples. Appl. Environ. Microbiol. 2003;69:3476-3483.

12. Zumft WG. Cell biology and molecular basis of denitrification. Microbiol. Mol. Biol. Rev. 1997;61:533-616.

13. Zumft WG. Nitric oxide reductases of prokaryotes with emphasis on the respiratory, heme-copper oxidase type. J. Inorg. Biochem. 2005;99:194-215.

14. Horn MA, Drake HL, Schramm A. Nitrous oxide reductase genes (nosZ) of denitrifying microbial populations in soil and the earthworm gut are phylogenetically similar. Appl. Environ. Microbiol. 2006;72:1019-1026.

15. Scala DJ, Kerkhof LJ. Nitrous oxide reductase (nosZ) gene-specific PCR primers for detection of denitrifiers and three nosZ genes from marine sediments. FEMS Microbiol. Lett. 1998;162: 61-68.

16. Stres B, Mahne I, Avgustin G, Tiedje JM. Nitrous oxide reductase (nosZ) gene fragments differ between native and cultivated
Michigan soils. Appl. Environ. Microbiol. 2004;70:301-309.

17. Smith CJ, Osborn AM. Advantages and limitations of quantitative PCR(Q-PCR)-based approaches in microbial ecology. FEMS Microbiol. Ecol. 2009;67:6-20.

18. Geets J, Cooman MD, Wittebolle L, et al. Real-time PCR assay for the simultaneous quantification of nitrifying and denitrifying bacteria in activated sludge. Appl. Microbiol. Biotechnol. 2007;75:211-221.

19. Philippot L. Use of functional genes to quantify denitrifiers in the environment. Biochem. Soc. Trans. 2006;34:101-103.

20. Smith CJ, Nedwell DB, Dong LF, Osborn AM. Evaluation of quantitative polymerase chain reaction-based approaches for determining gene copy and gene transcript numbers in environmental samples. Environ. Microbiol. 2006;8:804-815.

21. Wallenstein MD, Vilgalys RJ. Quantitative analyses of nitrogen cycling genes in soils. Pedobiologia. 2005;49:665-672.

22. Chon K, Chang JS, Lee E, Lee J, Ryu J, Cho J. Abundance of denitrifying genes coding for nitrate (narG), nitrite (nirS), and nitrous oxide (nosZ) reductases in estuarine versus wastewater effluent-fed constructed wetlands. Ecol. Eng. 2011;37: 64-69.

23. Fey A, Eichler S, Flavier S, Chrsitan R, Höfle MG, Guzman CA. Establishment of a real-time PCR-based approach for accurate quantification of bacterial RNA targets in water, using Salmonella as a model organism. Appl. Environ. Microbiol. 2004;70:3618-3623.

24. Neretin LN, Schippers A, Pernthaler A, Hamann K, Amann R, Jørgensen BB. Quantification of dissimilatory (bi) sulphite reductase gene expression in Desulfobacterium autotrophicum using real time PCR. Environ. Microbiol. 2003;5:660-671.

25. Wawrik B, Paul JH, Tabita FR. Real-time PCR quantification of rbcL (ribulose-1,5-bisphosphate carboxylase/oxygenase) mRNA in diatoms and pelagophytes. Appl. Environ. Microbiol. 2002;68:3771-3779.

26. Smith CJ, Nedwell DB, Dong LF, Osborn AM. Diversity and abundance of nitrate reductase genes (narG and napA), nitrite reductase genes (nirS and nrfA), and their transcripts in estuarine sediments. Appl. Environ. Microbiol. 2007;73:3612-3622.

27. Beller HR, Chain PSG, Letain TE, et al. The genome sequence of the obligately chemolithoautotrophic, facultatively anaerobic bacterium Thiobacillus denitrificans. J. Bacteriol. 2006;188: 1473-1488.

28. Henderson SL, Dandie CE, Patten C, et al. Changes in denitrifier abundance, denitrification gene mRNA levels, nitrous oxide emissions and denitrification in anoxic soil microcosm amended with glucose and plant residues. Appl. Environ. Microbiol. 2010;76:2155-2164.

29. Chon K, Kim Y, Chang NI, Cho J. Evaluating wastewater stabilizing constructed wetland, through diversity and abundance of the nitrite reductase gene nirS, with regard to nitrogen control. Desalination 2010;264:201-205.

30. López-Gutiérrez JC, Henry S, Hallet S, Martin-Laurent F, Catroux G, Philippot L. Quantification of a novel group of nitrate-reducing bacteria in the environment by real-time PCR. J. Microbiol. Methods. 2004;57:399-407.

31. Park N, Lee J, Chon K, Kang H, Cho J. Investigationg microbial activities of constructed wetlands, with respect to nitrate and sulfate reduction. Desalination Water Treat. 2009;1:172-179. 